\title{
Caspase-Independent Photoreceptor Apoptosis in Mouse Models of Retinal Degeneration
}

\author{
Francesca Doonan, Maryanne Donovan, and Thomas G. Cotter \\ Tumour Biology Laboratory, Biochemistry Department, Bioscience Research Institute, University College Cork, Cork, Ireland
}

\begin{abstract}
Apoptosis is the mode of cell death in retinitis pigmentosa, a group of retinal degenerative disorders primarily affecting rod photoreceptors. Although caspases have been demonstrated to play a central role in many incidences of apoptosis, accumulating evidence suggests that they may not be required for all forms of apoptotic cell death. The present study examined the mechanism of cell death in two in vivo models of photoreceptor apoptosis: the retinal degeneration (rd) mouse, a naturally occurring mutant model, and $N$-methyl- $N$ nitrosourea-induced retinal degeneration. Specifically, we examined the activation status of caspase- $9,-8,-7,-3$, and -2 and determined the caspase requirements for cytochrome $c$ release, DNA fragmentation, and apoptosis-associated proteolysis of specific caspase substrates. We show that apoptosis in both in vivo models is independent of caspase- $9,-8,-7,-3$, and -2 activation. DNA fragmentation occurs in the absence of caspase-mediated ICAD (inhibitor of caspase-activated DNase) proteolysis, suggesting that an alternative endonuclease is responsible for DNA cleavage in these models. Importantly, we show that apoptosome activation is prevented because of an absence of mitochondrial cytochrome $c$ release. Experiments performed using a cell-free system indicate that cytochrome $c$-dependent proteolysis and activation of caspase- 9 can be restored in a neonatal cell-free system. However, we found that cytochrome $c$-dependent proteolysis and activation of caspase-9 could not be restored in an adult cell-free system because of an age-related decrease in the expression of Apaf-1 in the normal developing mouse retina. In the rd mouse, however, this age-related downregulation of apoptotic proteins was not observed, highlighting a critical feature of this model and the prevention of cytochrome $c$ release as an apical event in caspaseindependent apoptosis in this system.
\end{abstract}

Key words: photoreceptor; apoptosis; caspase; independent; cytochrome $c$; rd; MNU

\section{Introduction}

Apoptosis is a mechanism of programmed cell death in which the cell plays an active role in its own demise. This form of cell death, although crucial to development, has been implicated in several neurodegenerative diseases, including the heterogeneous group of inherited retinal degenerations referred to as retinitis pigmentosa (RP). RP is characterized by an initial disturbance of night vision associated with a loss of rod photoreceptors, followed by a loss of peripheral vision and visual acuity caused by cone photoreceptor degeneration. The genetics of RP is complex: at least 30 genes have been implicated, many of which encode photoreceptor-specific proteins. Examples include the structural proteins peripherin (Farrar et al., 1992) and rod outer segment membrane protein 1 (Bascom et al., 1992) and proteins involved in the phototransduction cascade, rod GMP phosphodiesterase (McLaughlin et al., 1993) and rhodopsin (Farrar et al., 1990). Apoptosis, however, is a feature common to all of the cases of human RP and animal models of retinal degeneration (Chang et al., 1993).

In the retinal degeneration ( $\mathrm{rd}$ ) mouse, a mutation located in the gene encoding the $\beta$-subunit of rod cGMP phosphodiesterase

Received Aug. 12, 2002; revised Feb. 25, 2003; accepted April 8, 2003.

This work was supported by prize money from the Royal Dublin Society Irish Times Boyle Medal, the Health Research Board of Ireland, and Enterprise Ireland. In particular, we acknowledge Fighting Blindness Ireland for their continued support. We also acknowledge Dr. Justin McCarthy for his critical reading of this manuscript.

Correspondence should be addressed to Dr. Thomas G. Cotter at the above address. E-mail: t.cotter@ucc.ie. Copyright $\odot 2003$ Society for Neuroscience $\quad$ 0270-6474/03/235723-09\$15.00/0
(Bowes et al., 1990) causes accumulation of cGMP, resulting in photoreceptor apoptosis early in postnatal development (Lolley et al., 1994; Portera-Cailliau et al., 1994). Mutations in this gene are the most common cause of autosomal recessive RP in humans (McLaughlin et al., 1993), making it a particularly relevant model to study. Another model that has been shown to exhibit the primary event of RP, loss of photoreceptors by apoptosis, in mice, rats, and hamsters involves a single injection of $N$-methyl- $N$ nitrosourea (MNU) (Nakajima et al., 1996; Yuge et al., 1996; Nambu et al., 1997; Taomoto et al., 1998). MNU induces retinal degeneration via formation of 7-methyldeoxyguanosine DNA adducts in the nuclei of photoreceptors (Ogino et al., 1993).

The involvement of the caspase family of cysteine proteases in cell death is a topic of continuing debate. Initially, caspases were attributed a central role in the majority of apoptotic systems; however, increasing evidence suggests that certain features of apoptosis can be present in the absence of caspase activity (Borner and Monney, 1999). Caspase-independent apoptosis has been observed in neuronal cells in response to amyloid $\beta$, nitric oxide, and traumatic brain injury (Okuno et al., 1998; Selznick et al., 2000; Zhang et al., 2002) and in models of photoreceptor cell death both in vitro (Carmody and Cotter, 2000) and in vivo (Donovan and Cotter, 2002). Because both the nature and severity of an insult determine whether apoptosis is caspase dependent or independent (for review, see Nicotera, 2002), we investigated the potential involvement of caspases in two contrasting models of 
retinal degeneration, with varying severity of insult. In the spontaneous mutant rd mouse, the insult is chronic and increases in an age-dependent manner, inducing a relatively slow rate of death. In MNU-treated BALB/c mice, an acute, rapid, chemicalinduced model, significant retinal degeneration is evident within $48 \mathrm{hr}$.

We show that apoptosis in both in vivo models is independent of caspase- $9,-8,-7,-3$, and -2 activation. We further show that caspase- 9 activation is prevented because of an absence of mitochondrial cytochrome $c$ release. Experiments performed using a cell-free system indicate that cytochrome $c$-dependent proteolysis and activation of caspase- 9 can be restored in a neonatal cellfree system. However, we found that cytochrome $c$-dependent proteolysis and activation of caspase- 9 could not be restored in an adult cell-free system because of an age-related decrease in the expression of Apaf-1 in the normal developing mouse retina. These studies highlight prevention of cytochrome $c$ release as an apical event in caspase-independent activation in these in vivo models.

\section{Materials and Methods}

Animals. C57BL/6 (control), C3H/HEN (rd), and BALB/c animals were obtained from Harlan Olac (Bicester, UK). The animals were maintained in $12 \mathrm{hr}$ light/dark cycles and killed by cervical dislocation.

Intraperitoneal injections. Adult BALB/c mice were injected intraperitoneally with a single $75 \mathrm{mg} / \mathrm{kg}$ dose of MNU (Sigma, Dublin, Ireland) in $\mathrm{Me}_{2} \mathrm{SO}$. Control animals received vehicle only. Animals were killed by cervical dislocation 14, 24, and $48 \mathrm{hr}$ after treatment.

Cell lines. 32D cells were cultured in RPMI containing 10\% FCS and $10 \% \mathrm{WEHI}$-conditioned media. Apoptosis was induced by exposure to UV irradiation for 8-10 min. Jurkat T-cells were cultured in RPMI containing 10\% FCS. Apoptosis was induced using anti-human Fas (300 $\mathrm{ng} / \mathrm{ml}$ ) (Upstate Biotechnology, Lake Placid, NY).

Terminal deoxynucleotidyl transferase-mediated biotinylated UTP nick end labeling. Briefly, enucleated eyes were fixed in $10 \%$ neutral buffered formalin overnight at $4^{\circ} \mathrm{C}$, followed by cryoprotection in $30 \%$ sucrose overnight at $4^{\circ} \mathrm{C}$. Frozen sections $(5 \mu \mathrm{m})$ were incubated in $50 \mu \mathrm{l}$ of reaction buffer containing $2.5 \mathrm{~mm} \mathrm{CoCl}_{2}, 0.1 \mathrm{U} / \mathrm{ml}$ terminal deoxynucleotidyl transferase in a $0.1 \mathrm{M} \mathrm{Na}$ cocadylate, $\mathrm{pH} 7.0$, buffer, and $0.75 \mathrm{nM}$ fluorescein-12-deoxyuridine triphosphate (Boehringer Mannheim, Mannheim, Germany). Sections were incubated at $37^{\circ} \mathrm{C}$ for $1 \mathrm{hr}$ in a humidified chamber. After several washes in PBS, the sections were mounted in mowiol (Calbiochem, Nottingham, UK) and viewed under a fluorescence microscope (Nikon Eclipse E600) using an FITC filter.

Agarose gel electrophoresis. Enucleated eyes were placed in PBS, and retinal dissection was performed using a watchmaker's forceps. Retinal DNA was isolated using GenElute mammalian genomic DNA kit (Sigma). Extractions were performed according to the manufacturer's instructions except that retinas were initially incubated in $180 \mu \mathrm{l}$ of tissue lysis buffer containing proteinase $\mathrm{K}(20 \mu \mathrm{l} / \mathrm{ml})$ at $55^{\circ} \mathrm{C}$ for $8 \mathrm{hr}$. Electrophoresis was performed using $1.5 \%$ agarose gels and visualized under UV light after staining with ethidium bromide.

Western blot analysis. Retinas were dissected and lysed in radioimmunoprecipitation analysis (RIPA) buffer (50 mm Tris- $\mathrm{HCl}, \mathrm{pH} 7.4,1 \%$ NP-40, 0.25\% sodium deoxycholate, 150 mм NaCl, 1 mм EGTA, 1 mм sodium orthovanadate, $1 \mathrm{~mm}$ sodium fluoride) containing antipain (1 $\mu \mathrm{g} / \mathrm{ml})$, aprotinin $(1 \mu \mathrm{g} / \mathrm{ml})$, chymostatin $(1 \mu \mathrm{g} / \mathrm{ml})$, leupeptin $(0.1 \mu \mathrm{g} /$ $\mathrm{ml})$, pepstatin $(1 \mu \mathrm{g} / \mathrm{ml})$, and PMSF $(0.1 \mathrm{~mm})$. Equivalent amounts of protein, as determined by the Bio-Rad (Hemel Hempstead, UK) protein assay, using bovine serum albumin as standard, were resolved using SDSPAGE followed by transfer to nitrocellulose membrane (Schleicher \& Schuell, Dassel, Germany). Membranes were blocked for $1 \mathrm{hr}$ in $5 \%$ Blotto, followed by incubation overnight at $4^{\circ} \mathrm{C}$ with the appropriate antibodies. Antibodies reactive to caspase- 9 , caspase-3, caspase-7 (Cell Signaling Technology, Hertfordshire, UK), caspase-8, caspase-2, Apaf-1, (Santa Cruz Biotechnology, Santa Cruz, CA), poly(ADP)ribose polymerase (PARP) (PharMingen, San Diego, CA), inhibitor of caspase-activated
DNase (ICAD) (Oncogene Research Products, Nottingham, UK), cytochrome $c$ (Molecular Probes, Leiden, The Netherlands), $\beta$-actin (Sigma), and glyceraldehyde-3-phosphate dehydrogenase (GAPDH) (Advanced Immunochemical, Middlesex, UK) were used in this study. Membrane development was achieved using ECL (Amersham Biosciences, Buckinghamshire, UK).

Determination of acetyl-Asp-Glu-Val-Asp- $\rho$-nitroanilide cleavage. Retinas were dissected and washed in cold PBS. The tissue was homogenized in $50 \mu \mathrm{l}$ of lysis buffer (50 mM HEPES, pH 7.4, $100 \mathrm{~mm} \mathrm{NaCl}, 0.1 \%$ 3-[(3-cholamidopropyl)dimethylammonio]-1-propanesulfonate, 10 mM DTT, and $100 \mu \mathrm{m}$ EDTA) on ice for 20 min followed by three to four cycles of freeze thawing. Insoluble material was pelleted by centrifugation at $20,000 \times g$ for $15 \mathrm{~min}$ at $4^{\circ} \mathrm{C}$. Lysates were prepared from $32 \mathrm{D}$ and Jurkat cells in the same manner. The protein content of each sample was determined by Bio-Rad protein assay using bovine serum albumin as standard. An equal quantity $(80 \mu \mathrm{g})$ of retinal protein and positive control (32D or Jurkat) was loaded into each well of a microtiter plate. Lysates were incubated with an equal volume of $1 \times$ reaction buffer (as lysis buffer; plus $10 \%$ glycerol) and $50 \mu \mathrm{M}$ caspase- 3 substrate Asp-GluVal-Asp (DEVD)- $\rho$-nitroanilide ( $\rho \mathrm{NA}$ ) (Bahchem, Saffron Waldon, UK) at $37^{\circ} \mathrm{C}$ for $1 \mathrm{hr}$. Cleavage of the peptide substrate DEVD- $\rho$ NA was monitored by liberation of the chromogenic $\rho$ NA in a SpectraMax-340 plate reader (Molecular Devices, Menlo Park, CA) by measuring absorption at $405 \mathrm{~nm}$.

Subcellular fractionation. Separation of mitochondrial and cytosolic fractions was performed as follows: retinas were dissected in PBS and homogenized in lysis buffer $(210 \mathrm{~mm}$ mannitol, $70 \mathrm{~mm}$ sucrose, $5 \mathrm{~mm}$ HEPES, 1 mм EGTA, 0.05\% BSA, and 1 mм DTT) containing antipain (1 $\mu \mathrm{g} / \mathrm{ml})$, aprotinin $(1 \mu \mathrm{g} / \mathrm{ml})$, chymostatin $(1 \mu \mathrm{g} / \mathrm{ml})$, leupeptin $(0.1 \mu \mathrm{g} /$ $\mathrm{ml})$, pepstatin $(1 \mu \mathrm{g} / \mathrm{ml})$, and PMSF $(0.1 \mathrm{~mm})$. Disruption of the cell membrane was achieved by passage through a Pasteur pipette, followed by incubation on ice for $10 \mathrm{~min}$. After centrifugation at $1000 \times g$ for 5 $\min \left(4^{\circ} \mathrm{C}\right)$, the supernatant was retained. Additional centrifugation at $10,000 \times g$ for $20 \mathrm{~min}\left(4^{\circ} \mathrm{C}\right)$ yields a cytosolic fraction (supernatant) and a mitochondrial fraction (pellet). The pellet was resuspended in RIPA lysis buffer.

Preparation of cell-free extracts. Retinas were dissected in PBS and transferred to a $2 \mathrm{ml}$ Dounce homogenizer, and $120 \mu \mathrm{l}$ of cell extraction buffer (in mM: 20 HEPES, $10 \mathrm{KCl}, 1.5 \mathrm{MgCl}_{2}, 1$ EDTA, 1 EGTA, and 1 DTT) containing PMSF $(0.1 \mathrm{~mm})$, leupeptin $(10 \mu \mathrm{g} / \mathrm{ml})$, and aprotinin $(2 \mu \mathrm{g} / \mathrm{ml})$ was added. Cells were allowed to swell under hypotonic conditions for $15 \mathrm{~min}$ on ice. Cells were disrupted with 20 strokes of the pestle and incubated on ice for $15 \mathrm{~min}$. The lysate was transferred to an Eppendorf tube and centrifuged at 20,000 $\times g$ for $15 \mathrm{~min}$ at $4^{\circ} \mathrm{C}$. Cell-free extracts (CFEs) were incubated with cytochrome $c$ and $2^{\prime}$ deoxyadenoside triphosphate (dATP) at $37^{\circ} \mathrm{C}$ for $2 \mathrm{hr}$.

\section{Results}

\section{Detection of rod photoreceptor apoptosis in the rd mouse and MNU-treated BALB/c mice}

To establish a time course for retinal degeneration in both of our in vivo models, apoptosis was assessed by terminal deoxynucleotidyl transferase-mediated biotinylated UTP nick end labeling (TUNEL) of frozen retinal sections. The number of TUNELpositive cells in the rd mouse was comparable with that of wildtype (C57) mice until the second postnatal week when degeneration of rod photoreceptors in the outer nuclear layer (ONL) commenced. The level of apoptosis peaked at postnatal days 12-13 (P12-P13) (Fig. 1 Ai), with the process virtually completed by P15. Consistent with these observations, Portera-Cailliau et al. (1994) and Chang et al. (1993) have both confirmed the presence of apoptosis by detection of a DNA ladder. In contrast to the chronic rd model, in the more acute chemical-induced model of retinal degeneration, treatment with MNU resulted in the rapid induction of apoptosis, evident $14 \mathrm{hr}$ post-intraperitoneal injection, as determined by the appearance of TUNEL-positive nuclei in the ONL (Fig. 1 Aii) and observation of a characteristic DNA 
A

(i) $\mathbf{r d}$

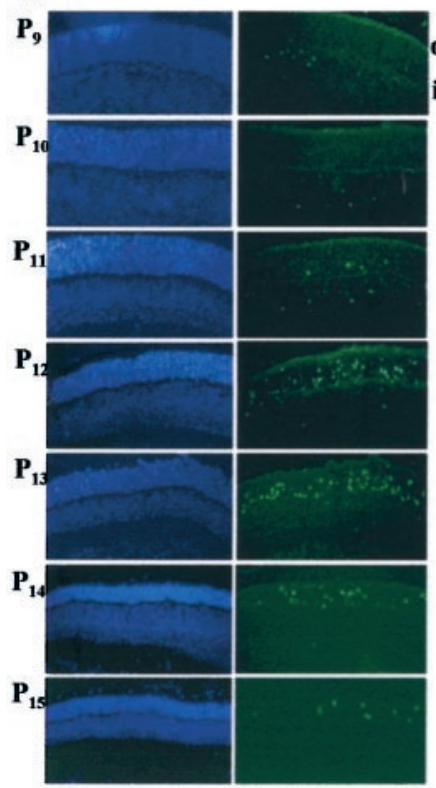

(ii) MNU Treated Balb/c

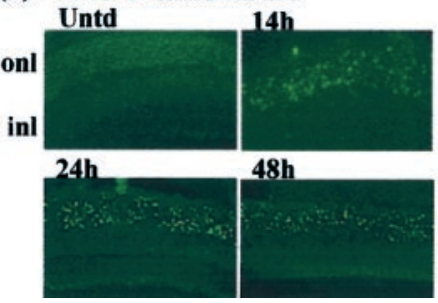

C57

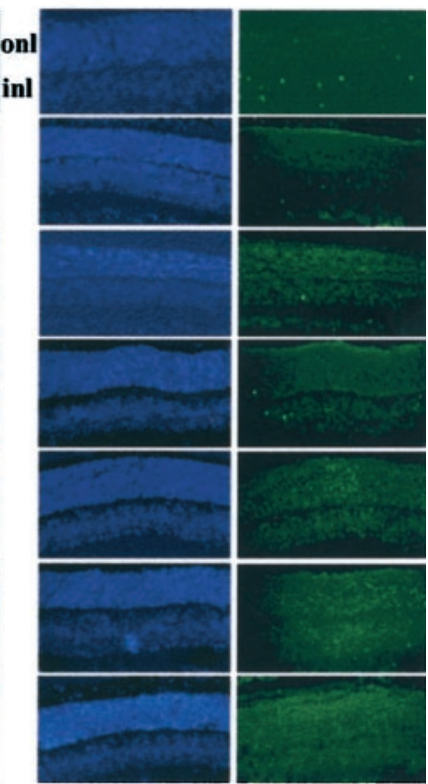

B MNU Treated Balb/c Untd 142448

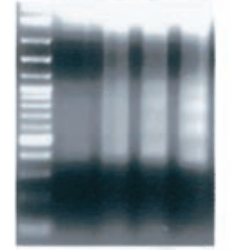

Figure 1. Detection of rod photoreceptor apoptosis in both the rd mouse and MNU-treated $\mathrm{BALB} / \mathrm{c}$ mice. $A$, Detection of rod photoreceptor apoptosis in rd and MNU-treated BALB/c mice. Apoptotic cell death was assessed by detection of DNA strand breaks in photoreceptor nuclei by TUNEL. $i$, Retinas of rd mice at P9 show scattered labeling of the inner nuclear layer (INL) because of a developmentally associated reduction in cell number. This developmental apoptosis is essentially complete by P10. A similar pattern is seen in 57 mice at P9 and P10. Scattered photoreceptor apoptosis is visible at P11 in the 0 NL, with significant apoptosis observed at P12 and P13. By P14, the number of TUNEL-labeled cells has diminished, correlating with the loss of photoreceptor layers. ii, Retina of untreated control BALB/c mice did not exhibit any TUNELpositive cells; however, $14 \mathrm{hr}$ after MNU treatment, scattered apoptosis is observed in the ONL. Time points examined 24 and $48 \mathrm{hr}$ after treatment reveal large numbers of apoptotic photoreceptor cells. B, Apoptosis was confirmed through detection of DNA fragmentation by agarose gel electrophoresis. The presence of a DNA ladder in MNU-treated mice 24 and $48 \mathrm{hr}$ after exposure (lanes 4 and 5 , respectively) confirms that apoptosis is the mode of cell death. Untd, Untreated.

ladder pattern (Fig. $1 B$ ). Increasing numbers of apoptotic cells were visible 24 and $48 \mathrm{hr}$ after treatment, by which time the thickness of the ONL had decreased significantly.

Photoreceptor apoptosis is independent of caspase- 3 in the rd mouse and in MNU-treated BALB/c mice

As a key executioner of apoptosis, the activity of caspase- 3 in both model systems was analyzed by Western blot and cleavage of the colorimetric substrate acetyl (Ac)-DEVD- $\rho$ NA. Caspase- 3 is synthesized as a $32 \mathrm{kDa}$ proenzyme that requires cleavage to its $17-20$ $\mathrm{kDa}$ active subunit. Levels of the 32 and $17-20 \mathrm{kDa}$ caspase-3 species were analyzed by Western blot, demonstrating the absence of active caspase- 3 in cell lysates taken from the retinas of $\mathrm{rd}$ mice from P9 to P15 (Fig. $2 \mathrm{Ai}$ ) and MNU-treated BALB/c mice 14, 24, and $48 \mathrm{hr}$ after exposure (Fig. $2 \mathrm{Aii}$ ). There was no visible

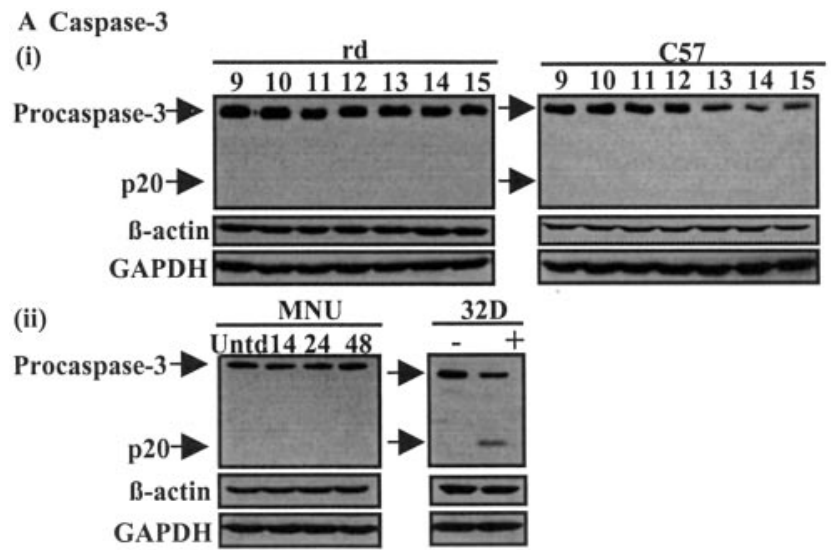

B

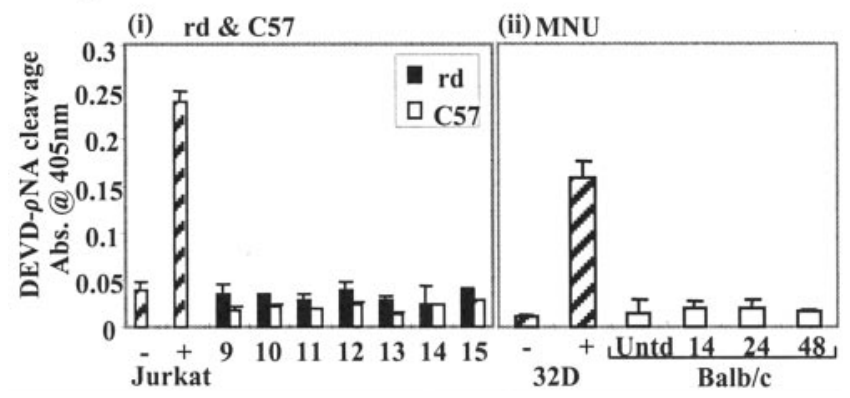

Figure 2. Caspase-3 is not activated during photoreceptor apoptosis in the rd mouse or in MNU-treated BALB/c mice. A, Analysis of caspase-3 activity by immunoblot. Retinal-cell lysates were taken from rd mice between P9 and P15 (i) and MNU-treated BALB/c mice 14, 24, and 48 hr after exposure (ii). Untreated $(-)$ and UV-treated $(+) 32 \mathrm{D}$ cells (apoptotic index, $<10 \%$ ) served as negative and positive controls, respectively, to confirm the ability of the antibody to detect the large 17-20 kDa active fragment of caspase-3. Bi, Bii, These cells demonstrated the processing of procaspase-3 $(32 \mathrm{kDa})$ to its active fragment of $17-20 \mathrm{kDa}$. $i$, Although procaspase-3 was detectable in retinal-cell lysates from rd mice at all of the time points examined, the 17-20 kDa fragment was absent up to P15. A similar pattern was observed in C57 retinal-cell lysates. ii, Equally, procaspase-3 was detectable in retinal-cell lysates from MNUtreated BALB/c mice at all of the time points examined; however, the $17-20 \mathrm{kDa}$ fragment was absent up to $48 \mathrm{hr}$. Each blot was reprobed with an antibody to $\beta$-actin to demonstrate equal protein loading, followed by an antibody to GAPDH to validate the use of actin as a loading control. $B$, Analysis of caspase-3-like activity by detection of DEVD- $\rho$ NA cleavage. The measurement of DVED- $\rho N A$ cleavage was performed in a spectrophotometric assay by monitoring the liberation of $\rho N A$ caused by caspase activity in rd retinal-cell lysates from P9 to P15 (rd, filled bars; $(57$, open bars) ( $i$ ) and retinal-cell lysates from MNU-treated BALB/c mice 14,24 , and 48 hr after exposure (open bars) (ii). Untreated (-) and anti-Fas IgM-treated (+) Jurkat cells (hatched bars) were used as negative and positive controls, respectively $(i)$. Similarly, untreated $(-)$ and UV-treated ( + ) 32D cells (hatched bars) were used as negative and positive controls, respectively (ii). An equal quantity of protein was loaded into each well. Data are expressed as the mean + SE of three independent experiments. Untd, Untreated; Abs., absorption.

decrease in rd procaspase-3 levels; however, an age-related decrease in procaspase- 3 protein levels was observed in C57 mice, which is discussed further below (see Fig. 6C). As a control for caspase- 3 activation, UV irradiation of the murine hematopoietic $32 \mathrm{D}$ cell line demonstrated the processing of procaspase- 3 to its $17-20 \mathrm{kDa}$ large fragment in a population of cells with an apoptotic index of $10 \%$. Western blots of retinal-cell lysates taken from age-matched C57 control mice demonstrated that any changes were specific to the rd mouse and not a feature of development (Fig. 2Ai). To demonstrate that actin was not degraded in our system and was therefore a valid loading control for subsequent blots, we also used GAPDH to demonstrate equal protein loading. The activity of the caspase-3-like protease was further analyzed by measuring the cleavage of the colorimetric substrate 


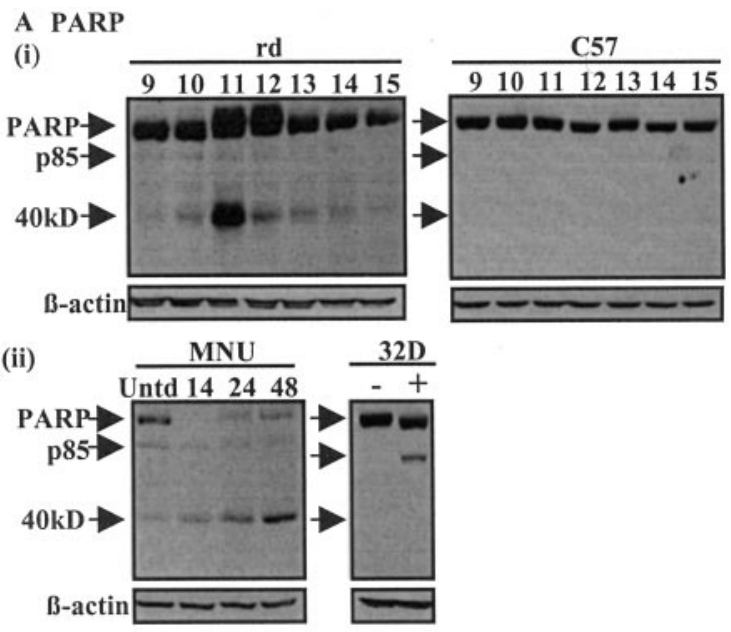

B ICAD
(i)

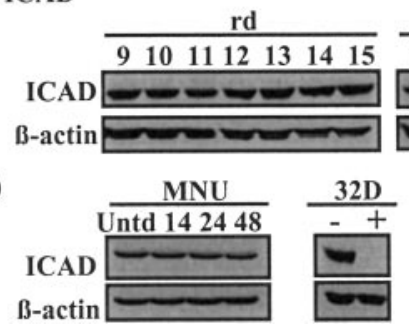

Figure 3. PARP and ICAD are not cleaved by caspase- 3 in the rd mouse and in MNU-treated $B A L B / c$ mice. Western blot analysis was performed to detect cleavage of PARP and ICAD. Retinal-cell lysates were taken from rd mice between $\mathrm{P} 9$ and P15 $(A i, B i)$ and MNU-treated BALB/c mice 14, 24, and $48 \mathrm{hr}$ after exposure (Aii, Bii). Untreated (-) and UV-treated (+) 32D cells (apoptotic index, $<10 \%$ ) served as negative and positive controls, respectively, to demonstrate the processing of PARP ( $116 \mathrm{kDa}$ ) to its cleaved fragment ( $85 \mathrm{kDa}$ ) and to confirm the ability of the antibody to detect murine ICAD ( $45 \mathrm{kDa})$. Ai, PARP levels decreased in the rd mouse from P12 onward; however, the $85 \mathrm{kDa}$ cleaved fragment was absent from P9 to P15. Levels of PARP remained constant in $C 57$ mice from P9 to P15. Aii, Native PARP levels decreased in treated $B A L B / c$ mice, whereas the $p 85$ fragment, present at basal levels in untreated BALB/c mice, did not increase. $B i$, ICAD did not undergo cleavage in the rd mouse at any of the time points examined. Bii, Similarly, cleavage of ICAD was not observed in MNU-treated mice at any of the time points examined. All of the blots were reprobed with an antibody to $\beta$-actin to demonstrate equal protein loading. A representative result of three experiments is shown. Untd, Untreated.

Ac-DEVD- $\rho$ NA. There was no evidence of Ac-DEVD- $\rho$ NA cleavage observed in rd retina (Fig. 2Bi) or in the MNU-treated $\mathrm{BALB} / \mathrm{c}$ retina (Fig. $2 \mathrm{Bii}$ ). Untreated and either UV-treated 32D cells or anti-Fas IgM-treated Jurkat cells served as negative and positive controls, respectively.

\section{PARP and ICAD were not cleaved by caspase- 3 in the $r d$ mouse and in MNU-treated BALB/c mice}

To verify further the absence of caspase- 3 activation in these two models of retinal degeneration, cleavage of the caspase- 3 substrate PARP was analyzed by Western blot. PARP is inactivated by cleavage from 116 to 85 and $25 \mathrm{kDa}$ fragments (Tewari et al., 1995). Western blot analysis using an antibody that detects both the 116 and $85 \mathrm{kDa}$ species demonstrated the absence of the 85 $\mathrm{kDa}$, caspase-3-specific cleavage product of PARP in retinal-cell lysates prepared from the retinas of rd mice from P9 to P15. A basal level of the p 85 fragment was present in untreated BALB/C mice, and this level did not increase in MNU-treated mice 14, 24, and $48 \mathrm{hr}$ after exposure, despite the onset of PARP cleavage (Fig. $3 A$ ). However, the disappearance of native PARP in the rd mouse from $\mathrm{P} 12$ to $\mathrm{P} 15$ and in MNU-treated BALB/c mice $14 \mathrm{hr}$ after treatment coincided with the appearance of a prominent band at $\sim 40 \mathrm{kDa}$, which increased over time in MNU-treated mice and was observed in the rd mouse particularly at P11. It is possible that an alternative protease (e.g., calpain), which yields a $40 \mathrm{kDa}$ product, may be cleaving and inactivating PARP (McGinnis et al., 1999).

Finally, we examined the activity of ICAD, a second caspase- 3 substrate $(45 \mathrm{kDa})$. ICAD exists in complex with caspaseactivated DNase (CAD) and is cleaved at two sites by caspase- 3 during apoptosis, releasing CAD (12 kDa) (Sakahira et al., 1998). Western blot analysis revealed the absence of ICAD cleavage in retinal-cell lysates prepared from the retinas of rd mice from P9 to P15 and MNU-treated BALB/c mice 14, 24, and $48 \mathrm{hr}$ after exposure (Fig. $3 B$ ). These results support the observation that caspase- 3 is not activated in either the naturally occurring mutant rd mouse or in an MNU-induced system. Surprisingly, the absence of ICAD cleavage in the presence of DNA fragmentation indicated the activation of an alternative endonuclease.

\section{Caspase- 7 and caspase- 2 were not activated during photoreceptor apoptosis in the rd mouse or MNU-treated BALB/c mice}

We next examined the activity of caspase-7, an alternative effector caspase, and caspase-2, which is reported to be involved in neuronal apoptosis through its action as an initiator or as an effector. Caspase- 7 is synthesized as a $35 \mathrm{kDa}$ inactive proenzyme that is cleaved to generate fragments of 20 and $12 \mathrm{kDa}$. Western blot analysis of cell lysates prepared from the retinas of rd mice from P9 to P15 and MNU-treated BALB/c mice 14, 24, and $48 \mathrm{hr}$ after exposure demonstrated the absence of cleaved caspase- 7 fragments (Fig. $4 A$ ). Induction of apoptosis by UV irradiation in the murine hematopoietic $32 \mathrm{D}$ cell line served as a positive control and demonstrated the processing of procaspase-7 $(35 \mathrm{kDa})$ to 20 and $12 \mathrm{kDa}$ fragments in a population of cells with an apoptotic index of $10 \%$. Caspase- 2 has been attributed an important role in neuronal apoptosis (Troy et al., 2000, 2001); indeed, it has been shown to function upstream of the mitochondria causing cytochrome $c$ release (Robertson et al., 2002) or downstream of caspase-3 as an effector caspase (Harvey et al., 1996). Procaspase- 2 is a $48 \mathrm{kDa}$ proenzyme that initially undergoes cleavage to 37 and $12 \mathrm{kDa}$ peptides. This $37 \mathrm{kDa}$ peptide may be processed further, yielding an $18 \mathrm{kDa}$ product. Western blot analysis of cell lysates prepared from the retinas of rd mice from $\mathrm{P} 9$ to P15 and MNU-treated BALB/c mice 14, 24, and $48 \mathrm{hr}$ after exposure demonstrated the absence of caspase-2 cleavage (Fig. $4 B$ ). UV-treated 32D cells served as a positive control and demonstrated the processing of procaspase-2 $(48 \mathrm{kDa})$ to its $12 \mathrm{kDa}$ peptide.

\section{Neither caspase-8 nor caspase-9 was activated during photoreceptor apoptosis in the rd mouse or MNU-treated BALB/c mice}

The activation status of both caspase-8, a mediator of receptoractivated apoptosis, and caspase-9, an important initiator caspase, were studied. Caspase- 8 is synthesized as a $53 \mathrm{kDa}$ inactive proenzyme that is processed into a cleaved $42 \mathrm{kDa}$ intermediate and 18 and $12 \mathrm{kDa}$ active fragments. We observed neither a decrease in the proenzyme nor the appearance of the $42 \mathrm{kDa}$ cleaved fragment in cell lysates prepared from the retinas of $\mathrm{rd}$ mice from P9 to P15 (Fig. 5Ai) and MNU-treated BALB/c mice 14, 24, and $48 \mathrm{hr}$ after exposure (Fig. 5Aii). The Jurkat cell line treated with anti-Fas IgM demonstrated the processing of the 53 $\mathrm{kDa}$ procaspase- 8 to its $42 \mathrm{kDa}$ fragment upon induction of ap- 
A Caspase-7

(i)

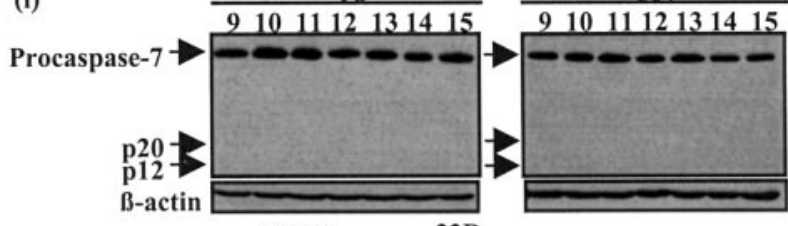

(ii)

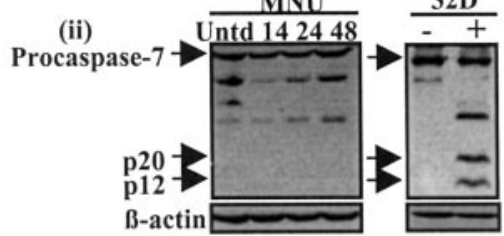

B Caspase-2
(i)

(i) Caspase-2

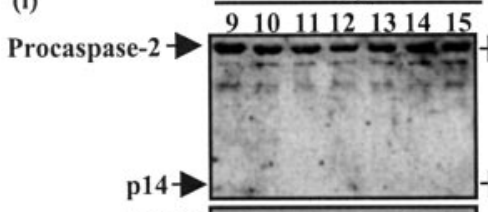

B-actin $--0--\longrightarrow$

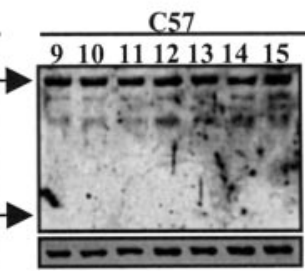

(ii)

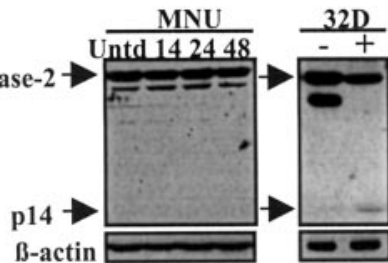

Figure 4. Caspase-7 and caspase-2 are not activated during photoreceptor apoptosis in the rd mouse or in MNU-treated BALB/c mice. A, Analysis of caspase-7 activity by immunoblot. Retinal-cell lysates were taken from rd mice between P9 and P15 ( $i$ ) and MNU-treated BALB/C mice 14, 24, and $48 \mathrm{hr}$ after exposure (ii). Untreated (-) and UV-treated (+) 32D cells (apoptotic index, $<10 \%$ ) served as negative and positive controls, respectively, to demonstrate the processing of procaspase- 7 ( $35 \mathrm{kDa}$ ) to its large $20 \mathrm{kDa}$ and small $12 \mathrm{kDa}$ fragments. The $35 \mathrm{kDa}$ species was present at all of the time points analyzed in the rd mouse; however, both cleaved fragments were absent up to P15. Procaspase-7 was detectable in retinal-cell lysates from MNU-treated BALB/C mice at all of the time points examined; however, both large and small cleaved fragments were absent even up to $48 \mathrm{hr}$. A positive $32 \mathrm{D}$ control has been included in this blot to rule out any ambiguity regarding the nonspecific bands observed in the MNU-treated samples. $B$, Analysis of caspase-2 activity by immunoblot. Retinal-cell lysates were taken from rd mice between P9 and P15 (i) and MNU-treated BALB/c mice 14, 24, and $48 \mathrm{hr}$ after exposure (ii). Untreated $(-)$ and UV-treated $(+) 32 \mathrm{D}$ cells (apoptotic index, $<10 \%$ ) served as negative and positive controls, respectively, to demonstrate the processing of procaspase-2 (48 $\mathrm{kDa}$ ) to its $12 \mathrm{kDa}$ product. The $48 \mathrm{kDa}$ species was present at all of the time points analyzed in the rd mouse; however, both cleaved fragments were absent up to P15. Procaspase-2 was detectable in retinal-cell lysates from $\mathrm{MNU}$-treated BALB/c mice at all of the time points examined; however, the large cleaved fragment was absent even up to $48 \mathrm{hr}$. All of the blots were reprobed with an antibody to $\beta$-actin to demonstrate equal protein loading. A representative result of three experiments is shown. Untd, Untreated.

optosis. Caspase-9, activated by release of cytochrome $c$ from mitochondria, is essential for the initiation of a cascade of caspase activity, including caspase-2, -3, -6, and -7 (Slee et al., 1999). This caspase is synthesized as a $45 \mathrm{kDa}$ proenzyme that undergoes cleavage to a large active $37-39 \mathrm{kDa}$ peptide and a small peptide. Analysis of caspase- 9 processing by Western blot demonstrated the absence of the large active subunit in cell lysates taken from the retinas of rd mice from P9 to P15 (Fig. 5Bi) and MNU-treated $\mathrm{BALB} / \mathrm{c}$ mice 14, 24, and $48 \mathrm{hr}$ after exposure (Fig. 5Bii). Induction of apoptosis by UV irradiation in the murine hematopoietic $32 \mathrm{D}$ cell line served as a positive control and demonstrated the processing of procaspase- $9(45 \mathrm{kDa})$ to its active $37-39 \mathrm{kDa}$ large fragment in a population of cells with an apoptotic index of $10 \%$.

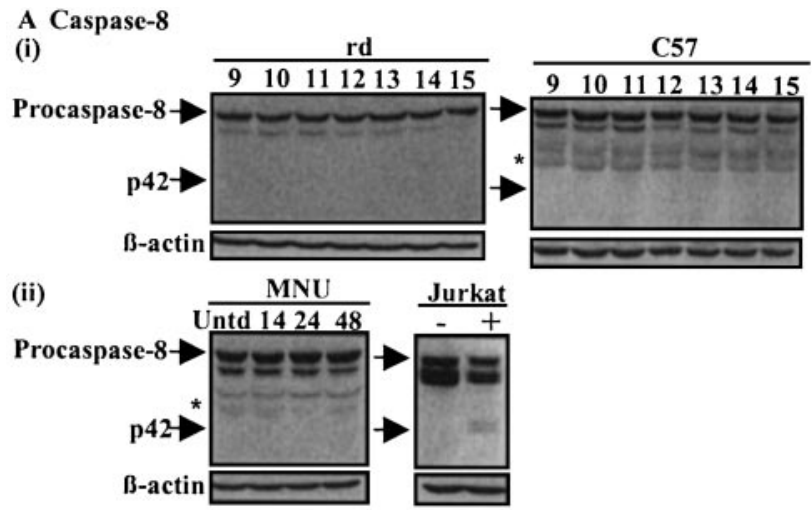

B Caspase-9

(i)
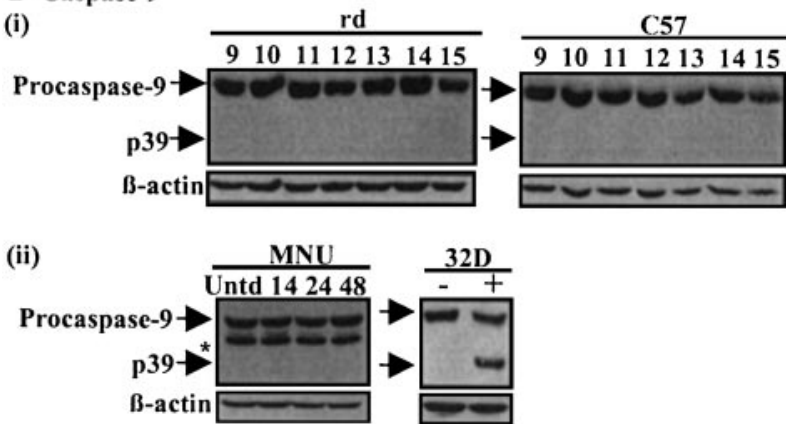

Figure 5. Neither caspase-8 nor caspase- 9 is activated during photoreceptor apoptosis in the rd mouse or MNU-treated BALB/C mice. A, Analysis of caspase-8 activity by immunoblot. Retinal-cell lysates were taken from rd mice between P9 and P15 ( $i$ ) and MNU-treated BALB/C mice 14, 24, and $48 \mathrm{hr}$ after exposure (ii). Untreated ( - ) and anti-Fas IgM-treated (+) Jurkat cells were used as negative and positive controls, respectively, to demonstrate the processing of procaspase-8 ( $53 \mathrm{kDa}$ ) to its $42 \mathrm{kDa}$ cleaved intermediate. The $53 \mathrm{kDa}$ species was present at all of the time points analyzed in the rd mouse; however, the $42 \mathrm{kDa}$ fragment was absent up to $\mathrm{P} 15$. Equally, procaspase-8 was detectable in retinal-cell lysates from MNU-treated BALB/c mice at all of the time points examined; however, the $42 \mathrm{kDa}$ active fragment was absent up to $48 \mathrm{hr}$ after treatment. *Nonspecific bands recognized by the antibody. $B$, Retinal-cell lysates were taken from rd mice between P9 and P15 (i) and MNU-treated BALB/c mice 14, 24, and $48 \mathrm{hr}$ after exposure (ii). Untreated ( - ) and UV-treated $(+) 32 \mathrm{D}$ cells (apoptotic index, $<10 \%$ ) served as negative and positive controls, respectively, to demonstrate the processing of procaspase- $9(46 \mathrm{kDa})$ to its large $37-39 \mathrm{kDa}$ active fragment. Although procaspase- 9 was detectable in retinal-cell lysates from rd mice at all of the time points examined, the $37-39 \mathrm{kDa}$ large fragment was absent up to P15. A similar pattern was observed in $\mathrm{C57}$ retinal-cell lysates. Equally, procaspase- 9 was detectable in retinal-cell lysates from MNU-treated BALB/c mice at all of the time points examined; however, the $37-39 \mathrm{kDa}$ fragment was absent even at $48 \mathrm{hr}$. All of the blots were reprobed with an antibody to $\beta$-actin to demonstrate equal protein loading. A representative result of three experiments is shown. *This band represents a caspase-9 splice variant present only in adult mice. Untd, Untreated.

Cytochrome $c$ was not released from the mitochondria in the rd mouse or after MNU treatment

Cytochrome $c$ is central to the initiation of a cascade of caspase activity through caspase-9. Release of cytochrome $c$ from the mitochondrial intermembrane space allows formation of the apoptosome, consisting of Apaf-1, caspase-9, dATP, and cytochrome $c$, which subsequently leads to the proteolytic cleavage and activation of caspase-9. The lack of caspase-9 cleavage during photoreceptor apoptosis led us to investigate the cellular localization of cytochrome $c$. Subcellular fractions were prepared from the retinas of rd mice from P9 to P15 and MNU-treated BALB/c mice 14, 24, and $48 \mathrm{hr}$ after exposure. Analysis by Western blot revealed that, in both cases, cytochrome $c$ was localized entirely in the mitochondria and did not translocate to the cytosol during photoreceptor apoptosis (Fig. 6A). UV irradiation of the murine hematopoietic $32 \mathrm{D}$ cell line demonstrated the release of cyto- 


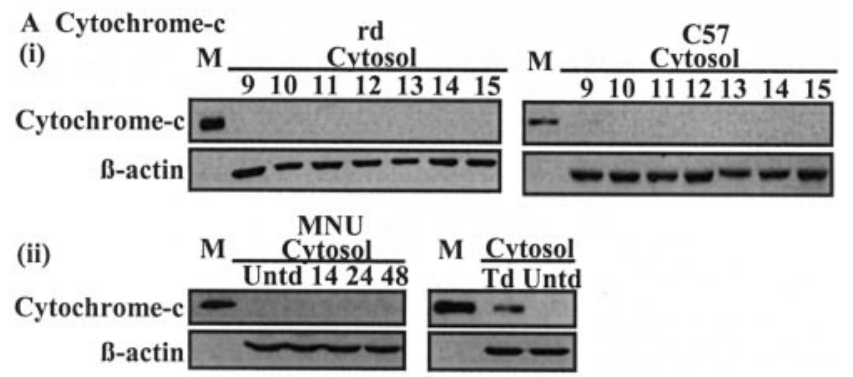

B Caspase-9

(i)

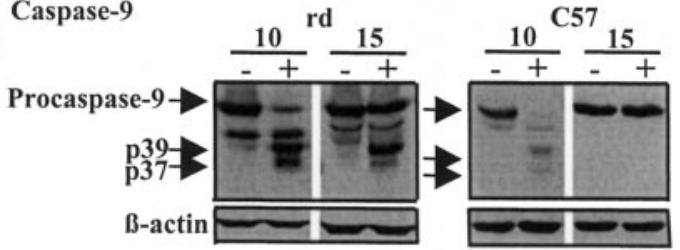

(ii)

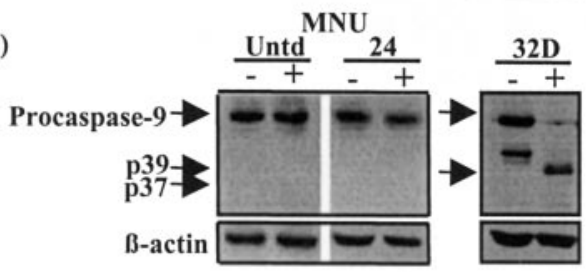

C

\begin{tabular}{|c|c|c|c|}
\hline & C57 & (ii) & C57 \\
\hline & $\begin{array}{llll}10 & 15 & 10 & 15\end{array}$ & & $\begin{array}{llll}10 & 15 & 10 & 15\end{array}$ \\
\hline af-1 & --- & Caspase- 3 & $-\cdots-\cdots$ \\
\hline B-actin & 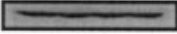 & B-actin & $=$ \\
\hline
\end{tabular}

Figure 6. Cytochrome $c$ is not released from mitochondria during photoreceptor apoptosis in the rd mouse or MNU-treated BALB/c mice. $A$, Cells were fractionated at each time point from $\mathrm{P} 9-\mathrm{P} 15$ in the rd mouse (i) and 14, 24, and $48 \mathrm{hr}$ after MNU treatment in BALB/c mice (ii). [Mitochondrial fractions were collected and analyzed for each time point (data not shown)]. The first lane was loaded with a representative mitochondrial fraction (M) as a positive control for cytochrome c. Cytochrome c was readily detectable in the mitochondrial fraction but was absent from the cytosol of rd mice at all of the time points examined. Cytochrome $c$ was also absent from the cytosol of MNU-treated BALB/c mice up to $48 \mathrm{hr}$ after treatment. Untreated and UV-treated $32 D$ cells served as negative and positive controls, respectively, to demonstrate the release of cytochrome c from the mitochondria into the cytosol. $B$, Retinal-cell-free extracts were prepared from rd mice between P9 and P15 (i) and MNU-treated BALB/c mice 14, 24, and $48 \mathrm{hr}$ after exposure (ii). Equivalent quantities of protein were incubated with cytochrome $c$ and dATP for $2 \mathrm{hr}$ and then resolved by SDS-PAGE, transferred onto nitrocellulose membrane, and probed with an antibody to caspase-9. Untreated $(-)$ and 32D-cell-free extracts incubated with cytochrome $\mathrm{c}(+)$ were used as a positive control to demonstrate the processing of procaspase- 9 to its large 37-39 kDa fragment. Caspase-9 was cleaved in the rd mouse at P10 and also at P15 after addition of cytochrome c. In 57 mice, however, caspase- 9 could be cleaved at P10, but not at P15, after cytochrome $c$ treatment. MNU-treated BALB/C mice retain caspase-9 9 in its inactive form; however, it was not cleaved on addition of cytochrome $c$. All of the blots were reprobed with an antibody to $\beta$-actin to demonstrate equal protein loading. A representative result of three experiments is shown. C, Apaf- 1 and caspase-3 are downregulated at P15 in 557 mice, but not in the rd mouse. Retinal-cell lysates were taken from rd and 57 mice at P10 and P15. Analysis of Apaf-1 protein levels indicated expression dropped significantly from P10 to P15 in 57 mice, but not in the rd mouse (Fig. 5A). Similarly, the levels of procaspase-3 decreased in $\mathrm{C} 57$ mice from $\mathrm{P} 10$ to $\mathrm{P} 15$, but not in rd mice (Fig. $5 B$ ). All of the blots were reprobed with an antibody to $\beta$-actin to demonstrate equal protein loading. A representative result of three experiments is shown. Untd, Untreated; Td, treated.

chrome $c$ from mitochondria into the cytosol. We also examined activation of caspase-12, because it has been implicated in cytochrome $c$-independent activation of caspase-9 (Morishima et al., 2002). Western blot analysis of caspase- 12 revealed that it is not expressed in the retinas of $\mathrm{BALB} / \mathrm{c}$, rd, and C57 strains; however, it is abundantly expressed in the murine $32 \mathrm{D}$ cell line (data not shown).

\section{Addition of cytochrome $c$ to cell-free extracts initiated activation of caspase- 9 in the rd mouse, but not in MNU- treated $\mathrm{BALB} / \mathrm{c}$ mice}

To confirm that the absence of cytochrome $c$ release directly prevented processing of caspase-9, we attempted to overcome this barrier by addition of cytochrome $c$ and dATP to cell-free systems. Cell-free extracts were prepared from the retinas of $\mathrm{rd}$ mice at P10 and P15. We discovered that caspase- 9 was cleaved on addition of cytochrome $c$ to cell-free extracts prepared from 10and 15-d-old rd retinas (Fig. 6 Bi). However, analysis of cell-free extracts, prepared from retinas of C57 mice at the same ages and treated with cytochrome $c$, indicated that, although caspase- 9 was susceptible to proteolysis at P10, it was not susceptible to cytochrome $c$-mediated proteolysis at P15 (Fig. 6 Bi). This indicated the existence of an additional barrier to caspase activation in a normal adult retina. Cell-free extracts were also prepared from the retinas of untreated and MNU-treated BALB/c mice $24 \mathrm{hr}$ after exposure and incubated with cytochrome $c$. Similarly, Western blot analysis demonstrated that caspase- 9 could not be processed to its active subunits in untreated adult BALB/c mice or 24 hr after MNU treatment (Fig. 6 Bii). These cell-free studies demonstrated that activation of the downstream caspase cascade is dependent only on cytochrome $c$ release in the rd mouse.

Apaf- 1 and caspase- 3 were downregulated at P15 in C57 mice, but not in the rd mouse

Release of mitochondrial cytochrome $c$ is a central event in caspase-dependent apoptosis. However, in our cell-free systems, the addition of cytochrome $c$ did not initiate the proteolytic cleavage and activation of caspase-9 in C57 mice at P15 in untreated adult $\mathrm{BALB} / \mathrm{c}$ mice, or adult $\mathrm{BALB} / \mathrm{c}$ mice treated with $\mathrm{MNU}$. This laboratory recently showed an age-related downregulation of apoptotic proteins, including Apaf-1, in adult BALB/c and C57 mice (from P10 to P60) and demonstrated that this decrease in Apaf-1 correlates with an age-related inability to activate caspase-9 in the presence of cytochrome $c$ (Donovan and Cotter, 2002). Because caspase- 9 could be processed in C57 mice at P10, but not at P15, we analyzed protein levels at these time points and discovered that both Apaf-1 and caspase- 3 expression were notably decreased at P15 in C57 mice (Fig. 6C). Significantly, in the rd mouse, there was no change in the expression of either protein, highlighting the inability of the cells to downregulate components of the apoptotic cascade while being exposed to an increasingly toxic insult.

\section{Discussion}

The purpose of this study was to analyze the activity of the caspase family of cysteine proteases in two models of in vivo photoreceptor apoptosis with differing severity of insult. It appears that there is increasing disparity between studies performed in cell systems compared with the actual disease state, highlighting the importance of in vivo models. In this regard, our results show that photoreceptor apoptosis in the rd mouse and in MNU-treated $\mathrm{BALB} / \mathrm{c}$ mice occurs independently of both cytochrome $c$ release and caspase activation (Figs. 2-6).

In particular, we studied the effectors caspase- 3 and -7 as well as the initiators caspase- 8 and -9 . We also examined the activity of caspase-2, which can function either downstream of caspase-3 as an effector caspase, or upstream of the mitochondria as an initiator. It is important to note that, although caspase- 2 was not cleaved in either of our in vivo models, a very recent report has demonstrated caspase- 2 activation without proteolysis in vitro (Read et al., 2002b). Finally, we considered caspase-12, because it 
has been implicated in cytochrome $c$-independent activation of caspase- 9 in response to endoplasmic reticulum stress, and discovered that it not expressed at the protein level in the mouse retina (data not shown). Caspase-independent apoptosis has been described previously in a number of model systems [e.g., death induced by amyloid- $\beta$ (Selznick et al., 2000), nitric oxide (Okuno et al., 1998), vitamin D compounds (Mathiasen et al., 2002), and depletion of heat shock protein-70 (Nylandsted et al., 2000), and after traumatic brain injury in rats (Zhang et al., 2002)]. Furthermore, this laboratory has described a pathway of light-induced photoreceptor apoptosis in vivo that is independent of caspases (Donovan and Cotter, 2002) and also a caspaseindependent pathway of retinal cell apoptosis in vitro (Carmody and Cotter, 2000). However, several studies show the activation of caspases in photoreceptor apoptosis [e.g., the RCS rat (Katai et al., 1999) and rhodopsin S334ter rats (Liu et al., 1999), and after treatment of rats with MNU (Yoshizawa et al., 1999, 2000), lead, or calcium (He et al., 2000)].

The results shown here are in direct contrast to a report of caspase activation during retinal degeneration in the rd mouse (Jomary et al., 2001). In this study, Jomary et al. (2001) employ polyclonal antibodies for immunocytochemistry; however, this technique can lead to false positives resulting from nonspecific binding. In addition, some of the antibodies used do not discriminate between inactive and active forms of caspases, and therefore, the result is somewhat inconclusive. A recent report by Yoshizawa et al. (2002) supports our conclusion that retinal degeneration in the rd mouse is caspase independent. In this study, injection of $\mathrm{rd}$ mice with the caspase- 3 inhibitor AcDEVD-CHO resulted in a transient effect with no protection provided after $13 \mathrm{~d}$ (Yoshizawa et al., 2002), indicating the existence of an alternative, caspase-independent pathway. Indeed, treatment of rd mouse retinal cell explants with $N$-benzyloxycarbonyl-DEVD-fluoromethylketone did not rescue rd photoreceptor cells (Caffe et al., 2001). It appears likely that cell type and both the nature and severity of the insult determine whether apoptosis is caspase dependent or independent (for review, see Nicotera, 2002).

Despite the apparent lack of caspase activity in either of our models, both exhibit DNA fragmentation, one of the key characteristics of apoptosis. Although CAD, which is activated by caspase-3, is the primary endonuclease identified, evidence exists that DNA fragmentation can occur independently of caspase activity. It has been shown that granzyme B can cleave ICAD in a caspase-independent manner, resulting in DNA fragmentation (Thomas et al., 2000). In addition, ICAD/CAD knock-out mice subjected to traumatic brain injury exhibit DNA fragmentation, indicating the existence of other endonucleases (Yakovlev et al., 2001a). A potential candidate is apoptosis-inducing factor, which is released from the mitochondria in response to apoptotic stimuli in a caspase-independent manner (Susin et al., 1999). Similarly, endonuclease- $\mathrm{G}$, released from mitochondria during apoptosis, has been attributed a role in some forms of caspaseindependent apoptosis (van Loo et al., 2001). It has also been shown that the $\mathrm{Ca}^{2+}$ - and $\mathrm{Mg}^{2+}$-dependent endonuclease DNAS1L3 can be inhibited by PARP (Boulares et al., 2002), and release from this inhibition requires PARP cleavage. Therefore, the caspase-independent degradation or cleavage of PARP that we observe in both models could allow activation of this endonuclease. It is evident that PARP is being cleaved or degraded in the rd mouse from P12 to P15 and after MNU treatment (Fig. 3A); however, this cleavage does not appear to be caspase- 3 dependent. The appearance of a $40 \mathrm{kDa}$ product present in both models may suggest a role for calpains, which are known to cleave PARP at alternative sites, generating fragments $40 \mathrm{kDa}$ in size (McGinnis et al., 1999). Calpains are cysteine proteases that exist as inactive proenzymes but can be activated by $\mathrm{Ca}^{2+}$ and autolytic processing in most forms of necrosis, but also in some forms of apoptosis. Neuronal calpains appear to be uncontrollably activated in a number of neurodegenerative diseases, including Alzheimer's disease (Tsuji et al., 1998), Parkinson's disease (MouattPrigent et al., 1996), and amyotrophic lateral sclerosis (Ueyama et al., 1998). Calpain isoforms have been implicated in ganglion cell death induced by ischemia-reperfusion in rat retinas in vivo (Sakamoto et al., 2000), with the calpain inhibitor SJA6017 inhibiting retinal damage in vitro (Tamada et al., 2002). In addition, calpain activity has been reported in the RCS rat (Azarian and Williams, 1995) and the light-induced mouse model of retinal degeneration (Donovan and Cotter, 2002). The intracellular $\mathrm{Ca}^{2+}$ concentration in rod photoreceptors is controlled by influx through cGMP-gated channels and efflux through $\mathrm{Na}^{+}-\mathrm{Ca}^{2+}-\mathrm{K}^{+}$exchangers. Therefore, aberrant levels of cGMP present in the rd mouse could lead to increased intracellular calcium influx, allowing calpain activation. In fact, it has been shown that, in rd mice lacking L-type voltage-dependent $\mathrm{Ca}^{2+}$ channels, photoreceptor degeneration is delayed (Read et al., 2002a). Thus, calcium entry by this mechanism could also contribute to cell death in this model. Consequently, calpains may represent a distinct family of cysteine proteases that can be activated during photoreceptor apoptosis.

To establish the point at which activation of the caspase cascade is prevented, we examined the intrinsic or mitochondrial pathway of cell death. This pathway requires release of cytochrome $c$ into the cytosol where it forms a complex with caspase-9 and Apaf-1. Subcellular fractionation studies revealed that cytochrome $c$ is not released from mitochondria in the $\mathrm{rd}$ mouse or in response to MNU treatment in BALB/c mice (Fig. $6 A$ ). Addition of cytochrome $c$ to rd cell-free extracts confirmed that the absence of cytochrome $c$ release was the only barrier to the activation of caspase- 9 in rd mice at both P10 and P15. It has been demonstrated that cGMP, through activation of protein kinase G, can prevent mitochondrial cytochrome $c$ release (Kim et al., 1999), and also that Akt can prevent processing and activation of caspases by maintaining mitochondrial integrity and preventing cytochrome $c$ release (Kennedy et al., 1999). Alternatively, the proapoptotic protein Bad may be a potential target for phosphorylation by Akt, thereby preventing Bad-induced cytochrome $c$ release (Datta et al., 1997). Analysis of Akt phosphorylation revealed that this species remains phosphorylated in the rd mouse despite the onset of apoptosis (data not shown).

Similarly, the absence of cytochrome $c$ release in MNUtreated BALB/c mice prevents activation of the caspase cascade; however, a supplementary mechanism prevents caspase- 9 activation. A possible explanation is provided by the observation that caspase- 9 may be activated by cytochrome $c$ in vitro in C57 cellfree extracts at $\mathrm{P} 10$ but is precluded from activation at $\mathrm{P} 15$, correlating with a significant age-related decrease in Apaf-1. Therefore, at some point between P10 (essentially the conclusion of developmental cell death) and P15, the ability to activate the caspase pathway in the retina of C57 mice is removed. Downregulation of Apaf- 1 and caspase- 3 has been demonstrated in adult BALB/c and C57 mice (Donovan and Cotter, 2002) and in the developing brain (Yakovlev et al., 2001b), with a corresponding increase in resistance to cytochrome $c$-mediated death. These findings are also supported by reports demonstrating a decrease in caspase- 3 mRNA and protein levels during brain development 
(de Bilbao et al., 1999; Mooney and Miller, 2000). However, we demonstrate here that the levels of caspase- 3 and Apaf- 1 are significantly reduced as early as P15, concomitant with the termination of caspase-dependent developmental apoptosis. This downregulation of apoptosis-related proteins may represent a mechanism by which mature, postmitotic, terminally differentiated photoreceptors protect against apoptotic stimuli.

This study describes photoreceptor apoptosis in two different in vivo models via a pathway that is independent of a number of key caspases. Despite the absence of caspase activation, characteristic features of apoptosis are retained, including DNA fragmentation. Caspases of the post-mitochondrial pathway are precluded from activation during photoreceptor apoptosis by the absence of cytochrome $c$ release. The key components of the apoptotic pathway are present in the rd mouse but cannot be activated because of a block on cytochrome $c$ release. In MNUtreated adult BALB/c mice, caspase activation is blocked primarily by the absence of cytochrome $c$ release from the mitochondria and secondarily by what appears to be a more general phenomenon of the adult mouse retina, i.e., the decrease in expression of two key components of the caspase-dependent apoptotic pathway. In conclusion, from our studies, it is evident that photoreceptors use a caspase-independent apoptotic pathway; therefore, targeting caspases with the aim of retarding or preventing photoreceptor apoptosis may not be sufficient, and alternative targets for potential therapeutic intervention must be identified.

\section{References}

Azarian SM, Williams DS (1995) Calpain activity in the retinas of normal and RCS rats. Curr Eye Res 14:731-735.

Bascom RA, Manara S, Collins L, Molday RS, Kalnins VI, McInnes RR (1992) Cloning of the cDNA for a novel photoreceptor membrane protein (rom-1) identifies a disk rim protein family implicated in human retinopathies. Neuron 8:1171-1184.

Borner C, Monney L (1999) Apoptosis without caspases: an inefficient molecular guillotine? Cell Death Differ 6:497-507.

Boulares AH, Zoltoski AJ, Contreras FJ, Yakovlev AG, Yoshihara K, Smulson ME (2002) Regulation of DNAS1L3 endonuclease activity by poly(ADP-ribosyl)ation during etoposide-induced apoptosis. Role of poly(ADP-ribose) polymerase-1 cleavage in endonuclease activation. J Biol Chem 277:372-378.

Bowes C, Li T, Danciger M, Baxter LC, Applebury ML, Farber DB (1990) Retinal degeneration in the rd mouse is caused by a defect in the beta subunit of rod cGMP-phosphodiesterase. Nature 347:677-680.

Caffe AR, Soderpalm AK, Holmqvist I, van Veen T (2001) A combination of CNTF and BDNF rescues rd photoreceptors but changes rod differentiation in the presence of RPE in retinal explants. Invest Ophthalmol Vis Sci 42:275-282.

Carmody RJ, Cotter TG (2000) Oxidative stress induces caspaseindependent retinal apoptosis in vitro. Cell Death Differ 7:282-291.

Chang GQ, Hao Y, Wong F (1993) Apoptosis: final common pathway of photoreceptor death in $\mathrm{rd}$, rds, and rhodopsin mutant mice. Neuron 11:595-605.

Datta SR, Dudek H, Tao X, Masters S, Fu H, Gotoh Y, Greenberg ME (1997) Akt phosphorylation of BAD couples survival signals to the cell-intrinsic death machinery. Cell 91:231-241.

de Bilbao F, Guarin E, Nef P, Vallet P, Giannakopoulos P, Dubois-Dauphin M (1999) Postnatal distribution of cpp32/caspase 3 mRNA in the mouse central nervous system: an in situ hybridization study. J Comp Neurol 409:339-357.

Donovan M, Cotter TG (2002) Caspase-independent photoreceptor apoptosis in vivo and differential expression of apoptotic protease activating factor-1 and caspase-3 during retinal development. Cell Death Differ 9:1220-1231.

Farrar GJ, McWilliam P, Bradley DG, Kenna P, Lawler M, Sharp EM, Humphries MM, Eiberg H, Conneally PM, Trofatter JA, Humphries P
(1990) Autosomal dominant retinitis pigmentosa: linkage to rhodopsin and evidence for genetic heterogeneity. Genomics 8:35-40.

Farrar GJ, Kenna P, Jordan SA, Kumar-Singh R, Humphries MM, Sharp EM, Sheils D, Humphries P (1992) Autosomal dominant retinitis pigmentosa: a novel mutation at the peripherin/RDS locus in the original $6 \mathrm{p}-$ linked pedigree. Genomics 14:805-807.

Harvey NL, Trapani JA, Fernandes-Alnemri T, Litwack G, Alnemri ES, Kumar S (1996) Processing of the Nedd2 precursor by ICE-like proteases and granzyme B. Genes Cells 1:673-685.

He L, Poblenz AT, Medrano CJ, Fox DA (2000) Lead and calcium produce rod photoreceptor cell apoptosis by opening the mitochondrial permeability transition pore. J Biol Chem 275:12175-12184.

Jomary C, Neal MJ, Jones SE (2001) Characterization of cell death pathways in murine retinal neurodegeneration implicates cytochrome $c$ release, caspase activation, and bid cleavage. Mol Cell Neurosci 18:335-346.

Katai N, Kikuchi T, Shibuki H, Kuroiwa S, Arai J, Kurokawa T, Yoshimura N (1999) Caspaselike proteases activated in apoptotic photoreceptors of Royal College of Surgeons rats. Invest Ophthalmol Vis Sci 40:1802-1807.

Kennedy SG, Kandel ES, Cross TK, Hay N (1999) Akt/protein kinase B inhibits cell death by preventing the release of cytochrome $c$ from mitochondria. Mol Cell Biol 19:5800-5810.

Kim YM, Chung HT, Kim SS, Han JA, Yoo YM, Kim KM, Lee GH, Yun HY, Green A, Li J, Simmons RL, Billiar TR (1999) Nitric oxide protects PC12 cells from serum deprivation-induced apoptosis by cGMP-dependent inhibition of caspase signaling. J Neurosci 19:6740-6747.

Liu C, Li Y, Peng M, Laties AM, Wen R (1999) Activation of caspase-3 in the retina of transgenic rats with the rhodopsin mutation s334ter during photoreceptor degeneration. J Neurosci 19:4778-4785.

Lolley RN, Rong H, Craft CM (1994) Linkage of photoreceptor degeneration by apoptosis with inherited defect in phototransduction. Invest Ophthalmol Vis Sci 35:358-362.

Mathiasen IS, Sergeev IN, Bastholm L, Elling F, Norman AW, Jaattela M (2002) Calcium and calpain as key mediators of apoptosis-like death induced by vitamin D compounds in breast cancer cells. J Biol Chem 277:30738-30745.

McGinnis KM, Gnegy ME, Park YH, Mukerjee N, Wang KK (1999) Procaspase- 3 and poly(ADP)ribose polymerase (PARP) are calpain substrates. Biochem Biophys Res Commun 263:94-99.

McLaughlin ME, Sandberg MA, Berson EL, Dryja TP (1993) Recessive mutations in the gene encoding the beta-subunit of rod phosphodiesterase in patients with retinitis pigmentosa. Nat Genet 4:130-134.

Mooney SM, Miller MW (2000) Expression of bcl-2, bax, and caspase-3 in the brain of the developing rat. Brain Res Dev Brain Res 123:103-117.

Morishima N, Nakanishi K, Takenouchi H, Shibata T, Yasuhiko Y (2002) An endoplasmic reticulum stress-specific caspase cascade in apoptosis. Cytochrome $c$-independent activation of caspase- 9 by caspase-12. J Biol Chem 277:34287-34294.

Mouatt-Prigent A, Karlsson JO, Agid Y, Hirsch EC (1996) Increased $\mathrm{M}$-calpain expression in the mesencephalon of patients with Parkinson's disease but not in other neurodegenerative disorders involving the mesencephalon: a role in nerve cell death? Neuroscience 73:979-987.

Nakajima M, Nambu H, Shikata N, Senzaki H, Miki H, Tsubura A (1996) Pigmentary degeneration induced by $\mathrm{N}$-methyl- $\mathrm{N}$-nitrosourea and the fate of pigment epithelial cells in the rat retina. Pathol Int 46:874-882.

Nambu H, Yuge K, Nakajima M, Shikata N, Takahashi K, Miki H, Uyama M, Tsubura A (1997) Morphologic characteristics of $N$-methyl- $N$ nitrosourea-induced retinal degeneration in C57BL mice. Pathol Int 47:377-383.

Nicotera P (2002) Apoptosis and age-related disorders: role of caspasedependent and caspase-independent pathways. Toxicol Lett 127:189-195.

Nylandsted J, Rohde M, Brand K, Bastholm L, Elling F, Jaattela M (2000) Selective depletion of heat shock protein 70 (Hsp70) activates a tumorspecific death program that is independent of caspases and bypasses Bcl-2. Proc Natl Acad Sci USA 97:7871-7876.

Ogino H, Ito M, Matsumoto K, Yagyu S, Tsuda H, Hirono I, Wild CP, Montesano R (1993) Retinal degeneration induced by $\mathrm{N}$-methyl- $\mathrm{N}$ nitrosourea and detection of 7-methyldeoxyguanosine in the rat retina. Toxicol Pathol 21:21-25.

Okuno S, Shimizu S, Ito T, Nomura M, Hamada E, Tsujimoto Y, Matsuda H (1998) Bcl-2 prevents caspase-independent cell death. J Biol Chem 273: 34272-34277. 
Portera-Cailliau C, Sung CH, Nathans J, Adler R (1994) Apoptotic photoreceptor cell death in mouse models of retinitis pigmentosa. Proc Natl Acad Sci USA 91:974-978.

Read DS, McCall MA, Gregg RG (2002a) Absence of voltage-dependent calcium channels delays photoreceptor degeneration in rd mice. Exp Eye Res 75:415.

Read SH, Baliga BC, Ekert PG, Vaux DL, Kumar S (2002b) A novel Apaf-1independent putative caspase-2 activation complex. J Cell Biol 159:739-745.

Robertson JD, Enoksson M, Suomela M, Zhivotovsky B, Orrenius S (2002) Caspase-2 acts upstream of mitochondria to promote cytochrome $c$ release during etoposide-induced apoptosis. J Biol Chem 277:29803-29809.

Sakahira H, Enari M, Nagata S (1998) Cleavage of CAD inhibitor in CAD activation and DNA degradation during apoptosis. Nature 391:96-99.

Sakamoto YR, Nakajima TR, Fukiage CR, Sakai OR, Yoshida YR, Azuma MR, Shearer TR (2000) Involvement of calpain isoforms in ischemiareperfusion injury in rat retina. Curr Eye Res 21:571-580.

Selznick LA, Zheng TS, Flavell RA, Rakic P, Roth KA (2000) Amyloid betainduced neuronal death is bax-dependent but caspase-independent. J Neuropathol Exp Neurol 59:271-279.

Slee EA, Harte MT, Kluck RM, Wolf BB, Casiano CA, Newmeyer DD, Wang HG, Reed JC, Nicholson DW, Alnemri ES, Green DR, Martin SJ (1999) Ordering the cytochrome $c$-initiated caspase cascade: hierarchical activation of caspases-2, $-3,-6,-7,-8$, and -10 in a caspase-9-dependent manner. J Cell Biol 144:281-292.

Susin SA, Lorenzo HK, Zamzami N, Marzo I, Snow BE, Brothers GM, Mangion J, Jacotot E, Costantini P, Loeffler M, Larochette N, Goodlett DR, Aebersold R, Siderovski DP, Penninger JM, Kroemer G (1999) Molecular characterization of mitochondrial apoptosis-inducing factor. Nature 397:441-446.

Tamada Y, Fukiage C, Daibo S, Yoshida Y, Azuma M, Shearer TR (2002) Involvement of calpain in hypoxia-induced damage in rat retina in vitro. Comp Biochem Physiol B Biochem Mol Biol 131:221-225.

Taomoto M, Nambu H, Senzaki H, Shikata N, Oishi Y, Fujii T, Miki H, Uyama M, Tsubura A (1998) Retinal degeneration induced by $N$-methyl- $N$-nitrosourea in Syrian golden hamsters. Graefes Arch Clin Exp Ophthalmol 236:688-695.

Tewari M, Quan LT, O’Rourke K, Desnoyers S, Zeng Z, Beidler DR, Poirier GG, Salvesen GS, Dixit VM (1995) Yama/CPP32 beta, a mammalian homolog of CED-3, is a CrmA-inhibitable protease that cleaves the death substrate poly(ADP-ribose) polymerase. Cell 81:801-809.

Thomas DA, Du C, Xu M, Wang X, Ley TJ (2000) DFF45/ICAD can be directly processed by granzyme $\mathrm{B}$ during the induction of apoptosis. Immunity 12:621-632.

Troy CM, Rabacchi SA, Friedman WJ, Frappier TF, Brown K, Shelanski ML
(2000) Caspase-2 mediates neuronal cell death induced by beta-amyloid. J Neurosci 20:1386-1392.

Troy CM, Rabacchi SA, Hohl JB, Angelastro JM, Greene LA, Shelanski ML (2001) Death in the balance: alternative participation of the caspase-2 and -9 pathways in neuronal death induced by nerve growth factor deprivation. J Neurosci 21:5007-5016.

Tsuji T, Shimohama S, Kimura J, Shimizu K (1998) m-Calpain (calciumactivated neutral proteinase) in Alzheimer's disease brains. Neurosci Lett 248:109-112.

Ueyama H, Kumamoto T, Fujimoto S, Murakami T, Tsuda T (1998) Expression of three calpain isoform genes in human skeletal muscles. J Neurol Sci 155:163-169.

van Loo G, Schotte P, van Gurp M, Demol H, Hoorelbeke B, Gevaert K, Rodriguez I, Ruiz-Carrillo A, Vandekerckhove J, Declercq W, Beyaert R, Vandenabeele P (2001) Endonuclease G: a mitochondrial protein released in apoptosis and involved in caspase-independent DNA degradation. Cell Death Differ 8:1136-1142.

Yakovlev AG, Di X, Movsesyan V, Mullins PG, Wang G, Boulares H, Zhang J, $\mathrm{Xu}$ M, Faden AI (2001a) Presence of DNA fragmentation and lack of neuroprotective effect in DFF45 knockout mice subjected to traumatic brain injury. Mol Med 7:205-216.

Yakovlev AG, Ota K, Wang G, Movsesyan V, Bao WL, Yoshihara K, Faden AI (2001b) Differential expression of apoptotic protease-activating factor-1 and caspase- 3 genes and susceptibility to apoptosis during brain development and after traumatic brain injury. J Neurosci 21:7439-7446.

Yoshizawa K, Nambu H, Yang J, Oishi Y, Senzaki H, Shikata N, Miki H, Tsubura A (1999) Mechanisms of photoreceptor cell apoptosis induced by $N$-methyl- $N$-nitrosourea in Sprague-Dawley rats. Lab Invest 79:1359-1367.

Yoshizawa K, Yang J, Senzaki H, Uemura Y, Kiyozuka Y, Shikata N, Oishi Y, Miki H, Tsubura A (2000) Caspase-3 inhibitor rescues $N$-methyl-Nnitrosourea-induced retinal degeneration in Sprague-Dawley rats. Exp Eye Res 71:629-635.

Yoshizawa K, Kiuchi K, Nambu H, Yang J, Senzaki H, Kiyozuka Y, Shikata N, Tsubura A (2002) Caspase-3 inhibitor transiently delays inherited retinal degeneration in $\mathrm{C} 3 \mathrm{H}$ mice carrying the rd gene. Graefes Arch Clin Exp Ophthalmol 240:214-219.

Yuge K, Nambu H, Senzaki H, Nakao I, Miki H, Uyama M, Tsubura A (1996) $N$-methyl- $N$-nitrosourea-induced photoreceptor apoptosis in the mouse retina. In Vivo 10:483-488.

Zhang X, Chen J, Graham SH, Du L, Kochanek PM, Draviam R, Guo F, Nathaniel PD, Szabo C, Watkins SC, Clark RS (2002) Intranuclear localization of apoptosis-inducing factor (AIF) and large scale DNA fragmentation after traumatic brain injury in rats and in neuronal cultures exposed to peroxynitrite. J Neurochem 82:181-191. 